\title{
The Complexity of Narrative Comparisons in Wollstonecraft's Maria; Or, The Wrongs of Woman and Lennox's The Female Quixote
}

Anne Lappert

\section{Introduction}

Comparisons are omnipresent and have served as "one of the key movements of thought and method" in philosophy and the sciences since antiquity (Eggers 2019: 33). The same applies to comparative practices in literature. As a constituent part of several rhetorical devices, comparing can be traced back as far as Aristotle's Rhetoric (see Cope 1867: 374, 446-447). And as a rhetorical strategy, it can serve to highlight differences, to point out similarities, and of course to get argumentative points across. While this observation may seem unremarkable or even trivial, it is all the more noteworthy that a thorough analysis of the wider spectrum of comparative practices is not available as of yet. This is especially true for textual practices of comparing in the novel. While some literary 'methods' of comparing such as the rhetorical devices of metaphor and metonymy have been thoroughly investigated, ${ }^{1}$ other aspects of comparing in literature, for example, in narrative texts such as novels, remain understudied. ${ }^{2}$ Once we turn from the investigation of comparison as a methodological issue, for instance, to the study of comparisons as textual

For introductions to the study of metaphor, see Punter (2007) and Evans/Creen (2006: 286-325).

2 For an introductory exploration of different aspects of comparing in literature, see Erhart (2020), who discusses a distinction between inner-textual comparisons, comparisons as narrative features, and comparisons in terms of metaphors. For reflections on the general relationship between narration and comparison and the function of comparing in literature, see also Kramer et al. (2020), Schneider (2017), and the contribution by Hartner/Schneider to this volume. 
practices that serve argumentative purposes, many questions remain unasked - especially with regard to issues of ideology. As Epple/Erhart (2015: 14-15) remind us, understanding comparative practices generally requires us to take a closer look at who compares what for which purposes in order to understand the ideological premises underlying a particular practice of comparing. However, when dealing with a novel, this is not enough. In order to analyze the ideological investment underlying a particular comparative practice in narrative fiction, it is just as necessary to look at how the individual comparisons forming this practice function in the argumentative structure of the text.

In their contribution to this volume, Marcus Hartner and Ralf Schneider take a first step towards the investigation of narrative practices of comparing. They turn to practices that compare and/or prompt comparisons in the eighteenth-century novel and show that texts from this period display an excessive concern with manners of conduct and social customs. Applying a heuristic differentiation into direct and indirect comparisons they indicate that eighteenth-century novels show a preference for indirect comparisons that come in a variety of forms. Taking their argument as a point of departure, I attempt to add to their survey by offering an analysis of two eighteenth-century novels, Mary Wollstonecraft's Maria; Or, The Wrongs of Woman (1798) and Charlotte Lennox's The Female Quixote (1752). My analysis specifically zooms in on narrative comparisons of social practices by focusing on the novels' ways of addressing questions of female rights and education in order to foreground the complexity and interlocking nature of different practices of comparing in literature. In my contribution to this volume, I attempt to complement the distinction offered by Hartner/Schneider and, in doing so, I intend to illustrate the complex, diverse and multi-layered form of comparative practices in the eighteenth-century novel.

In the following, I will argue that with regard to Maria; Or, The Wrongs of Woman and The Female Quixote, a distinction into direct and indirect comparisons does not suffice. Instead, a differentiation into at least three basic types, namely imagery comparisons, narrative comparisons and intertextual comparisons is necessary in order to illustrate how the two works' individual practices of comparing serve the feminist arguments posed in those texts. The chapter takes a closer look at how each suggested type of comparison operates to suit its respective argumentative purpose. Based on this analysis, it suggests that it is not sufficient to study the occurrence of comparisons as rhetoric devices. Rather, to analyze comparative arguments in narrative texts, it is crucial to investigate which practices of comparing are employed and 
what purposes their concrete form serves in the literary construction of the presented argument. To analyze the power and complexity of comparisons in literary texts, it is not enough to look at who compares what for which purpose. We also need to examine how such comparisons work on a textual level. While the importance of the latter aspect might seem minor, I will show that the meaning retrievable from the works by Wollstonecraft and Lennox changes significantly if the full spectrum of comparative practices is taken into consideration in their analysis.

\section{Types of Comparing in Mary Wollstonecraft's Maria; Or, The Wrongs of Woman}

In Maria; Or, The Wrongs of Woman, the female and the male characters are connected via the novel's protagonist Maria. In the text, the latter marries George Venables to get away from her family, particularly from her despotic brother, but this plan backfires. She gives birth to a daughter that is withheld from Maria by George. He confines Maria to an asylum, where she meets and befriends a member of staff, Jemima. Maria and a male inmate, Henry Darnford, fall in love and Darnford is eventually sued by George for the seduction of his wife Maria. Maria gives birth to a child from Darnford that eventually dies. Darnford leaves both, the country and Maria.

In a first step, a number of direct and indirect comparisons on the intratextual level of communication between characters can be distinguished. According to Hartner and Schneider we can generally speak of a direct comparison in narrative fiction when "at least two comparata (primum comparandum and secundum comparatum) or both these comparata and the tertium comparationis" are explicitly mentioned in a text. In contrast, they define indirect comparisons as the "positioning of comparata in a novel without the explicit naming of the tertium" - a strategy that serves as "an offer by the text" inviting readers to construct comparability by searching for and adding a suitable tertium themselves (see the contribution by Hartner/Schneider in this volume). Despite numerous indirect comparisons both Maria and Jemima occasionally also use direct comparisons. For example, Maria compares her own situation to that of Darnford. Darnford and Maria are both inmates in the asylum when Maria finds notes by Darnford in one of the books she received from Jemima. These notes are read by Maria as secret messages and establish a first communication between Maria and Henry Darnford before they are able to meet 
in person. Thus, a link is created between the two characters via Darnford's secret message in the book that is eventually read by Maria (18). Jemima also repeatedly uses direct comparisons to illustrate her situation as an orphan being treated like an animal by her foster family. She describes being kicked about "like a dog or cat", or "like a mule", and being "view[ed] [...] as a creature of another species" (Maria, 48-49; see also 18-19). But while the distinction into direct and indirect comparisons can be a helpful means of a first general orientation, it tells us little about the complex structures and interrelations of different comparative practices at work in a specific text. While Jemima uses direct comparisons to illustrate how she has been treated, for instance, she simultaneously indirectly compares her own situation to that of an imaginary girl that enjoys the protection of a loving mother. When she states that it was the lack "of the grand support in life - a mother's affection" that was her greatest misery, she invites the reader to imagine how different her life could have been with a loving mother by her side (see 37, 40). Though not directly or explicitly comparing her situation with that of a daughter protected by a loving mother, the daughter position as such serves as the shared feature, the tertium comparationis, of this indirect comparison; she implies that the daughter protected by a mother and the daughter who must make do without such protection have very little in common. However, the passage can also be read as a warning that a girl has hardly any protection but her mother; the argument is thus geared to demand a better protection for girls and women.

Jemima's comparisons of her situation as an orphan in a foster family, in general, and of an orphan daughter, in particular, to a child protected by a loving mother can be differentiated according to the categories 'direct' and 'indirect'. However, the example already makes apparent the problem of this kind of distinction. Both types of comparison can be differentiated according to the absence or presence of comparative particles. Yet, it would be a mistake to read both cases as separate from each other. Instead, the example illustrates that both types work together. While the direct comparison paints an image of Jemima's situation as a motherless child, the indirect comparison complements her descriptions by drawing on said image to bring in a gender aspect and to create a harsh contrast between an orphan girl and a beloved daughter. In other words, the direct comparison of Jemima to animals is related to the indirect comparisons which contrasts the level of protection enjoyed by a beloved daughter in the care of her mother to that of an orphan girl. Furthermore, both comparisons work by inviting images of the actual living situation of orphan girls and protected daughters. Hence, the warning 
against a lack of protection for girls is constructed by a complex network of direct and indirect comparisons that both heavily rely on creating an image of the suffering of orphan girls for the reader. This indicates that both, direct and indirect comparisons can be embedded in larger structures of meaning, but the distinction alone does not offer much insight in terms of what functions a comparison serves in these structures.

Another problem with the straightforward characterization of comparisons as either direct or indirect is that it narrows down the attention to the presence and absence of linguistic markers instead of highlighting the more subtle comparative structures embedded into a text. In the case of Maria; Or, The Wrongs of Woman the narrative structure of the novel is of interest, considering that two passages are set off from the rest of the text by their narrative voice, but also in terms of genre, because they offer two embedded narratives in the form of autobiographies. Jemima narrates her life story shortly before Maria narrates her own (Maria, 36-52, 59-109). At these two successive points the narrator changes from an extradiegetic, heterodiegetic to an intradiegetic, autodiegetic narrator thereby inviting a comparison between both text passages. These deviations from the initial heterodiegetic narrative situation highlight the two text passages. The recognition that Jemima and Maria are telling their own stories is indispensable to understand the plot and this realization can only be arrived at by way of comparing. At this point any attempt at figuring out why and in how far these passages are different immediately invites a further and more detailed comparison between both passages and between each part with the rest of the narrative. This then leads to the recognition that both embedded narratives share certain narrative, generic, and plot features: they are narrated by a woman sharing her story autobiographically in first person: both narratives revolve around an unhappy childhood and youth that places both women in the asylum. The accounts relate how both women's lives become unbearable after the deaths of their mothers. Both women experience rejection by their fathers and abuse. Jemima is physically abused by her father and her stepmother (38-39) and her later master (40-41). Maria is emotionally abused by her despotic brother and her ill-tempered father (70-72). Neither of them is protected by their fathers and both women can only escape from those forms of abuse to other forms of abuse (71). Jemima must leave her master's house after she is found pregnant with his child (42). She works as a prostitute and eventually becomes a servant to a master who keeps her for pleasure (44-45). After his death, she starts working in the asylum. Maria escapes her tyrannic brother by marry- 
ing George Venables (73), who betrays Maria and bankrupts her. Before Maria has a chance to get a divorce, George confines her to an asylum to get unhindered access to the money she inherited from her uncle. What is interesting is that the autobiographies, because of their succession and their similarities in content and narrative structure, question the status of marriage as a protection for women. Both Jemima and Maria are raped by men who presumably 'own' them. Jemima is 'owned' by her master; Maria is 'owned' by her husband. Both narratives employ a language that frames women as possessions by stating that the female characters are "introduced as an object" or, "born a slave", and the female characters lament that they are "a common property", or "the property of their husbands" (Maria 39, 40-43, see also: 78). Hence, the novel discusses questions of absolute authority between social classes as well as between men and women and can be classified as a Jacobin novel.

By vividly portraying the cruel fate of the two characters, Wollstonecraft's novel criticizes the fact that 'wife' and 'servant' are legally speaking in a similar position. They are the 'goods' of men and completely depend on the kindness and favour of the men who 'keep them. ${ }^{3}$ This connects to the author's arguments in her essay A Vindication of the Rights of Woman (1792), where she demands that women should not be regarded as the property of their husbands but as independent human beings worthy of a rational education; it also connects to A Vindication of the Rights of Men (1790) where Wollstonecraft attacks what she sees as an unjust class system under the absolute authority of a monarch. By comparing the narratives of Jemima and Maria, along with the arguments proposed in Wollstonecraft's two earlier political texts, the reader is thus invited to compare marriage to servanthood - a comparison that simultaneously criticizes the inhumane class system of contemporary society and the legal situation of women in marriage (Maria 52, 67, 87, 104; Rights of Men 95; Taylor 2003: 64). While A Vindication of the Rights of Woman and A Vindication of the Rights of Men are political and philosophical essays, Maria; Or, The Wrongs of Woman is a novel. This generic difference allows the novel to take up upon his lawful wife, for by their mutual consent and contract the wife hath given up herself in this kind unto her husband, which she cannot retract." Here it suffices to acknowledge that this argument was posed in public discourses and that the first recorded prosecution of a husband for raping his wife is dated no earlier than 1949 after a prior separation of the two and no earlier than 1991 while the marriage was still upheld (Han 1989: 113). For a more detailed discussion of the subject, see King (1998). 
the arguments developed in Wollstonecraft's two earlier essays, as the reader is invited to reconstruct and relate those arguments in the comparison between Jemima's and Maria's autobiographies. Hence, the comparison between those passages prompted by the novel's narrative structure is closely interlinked with an intertextual comparison between the text and the author's two political works. By drawing attention to the similar situation of both women despite their difference in social class, the novel reveals Wollstonecraft's feminist arguments and her political argument against monarchy to form related issues.

However, intertextual comparisons in Maria; Or, The Wrongs of Women are by no means limited to Wollstonecraft's own texts; they also relate to popular (literary) works by other writers. ${ }^{4}$ So, for instance, an intertextual link can be discerned between Maria's and Darnford's relationship and that of the characters Armida and Rinaldo in Torquato Tasso's epic poem Jerusalem Delivered (Gerusalemme liberata, 1581). Again, this link makes use of complex interlocking structures of comparing in order to pose an argument against marriage as a form of protection for women. The heterodiegetic narrator in Wollstonecraft's novel describes the connection between Maria and Darnford as so strong that "paradise bloomed around them; or they, by a powerful spell, had been transported into Armida's garden" (Maria 35). This reference points to Tasso's epic poem, in which the sorceress Armida abducts the Christian knight Rinaldo and takes him to her enchanted garden where they fall in love. ${ }^{5}$ Once the spell is broken Rinaldo leaves Armida heartbroken to continue the crusade. Armida becomes suicidal and is eventually saved by Rinaldo, who also convinces her to become Christian.

Armida's garden thus stands for a love that is illusional. Even though in Tasso's narrative Armida and Rinaldo end up together, the garden remains a general image of being deceived and under somebody's spell and thereby already installs a flicker of intertextual doubt as to the sincerity and endurance of Maria's and Darnford's relationship. The foreshadowing of disappointment

Theories of intertextuality, a term initially coined by Julia Kristeva, suggest that intertextually forms an essential aspect of all (literary) works. Texts never stand alone but are always interlinked with other texts. For an introduction to the history and theory of intertextuality, see Allen (2000).

5 While the remark of Armida's garden might not be immediately apparent nor resonate with contemporary readers, it is important to keep in mind the popularity of the Tasso's epic all across Europe well into the eighteenth-century (Durant/Durant 1961: 260-1). 
by comparing their current situation to Armida's garden is then fulfilled in the story when Venables successfully files a lawsuit against Darnford for the seduction of Maria (126). Darnford eventually leaves for another country (136) and after the death of her and Darnford's child Maria becomes suicidal. In one fragmented version of the ending she eventually takes her own life, while in another version, like with Armida and Rinaldo, Maria is rescued by Jemima (Maria 136-137). Armida's garden thus serves as a metaphor for a state of (romantic) illusion. ${ }^{6}$ George Lakoff and Mark Johnson define a metaphor as "understanding and experiencing one kind of thing in terms of another" (5) assuming that "every experience takes place within a vast background of cultural presuppositions" (57). Here Maria's relationship with Darnford is made sense of in the context of the magical garden of Armida. The metaphor implies that Maria does not see the situation clearly. Once the metaphor successfully invites the reader to reflect Maria's and Darnford's relationship in terms of Armida's garden, it also, in a second step, invites the reader to compare her relationship with Darnford to her marriage with Venables. Both men deceive Maria to take advantage of her. Her husband Venables takes advantage of Maria financially, while Darnford takes physical advantage of Maria leaving her with a dead child (131-132, 136). Both men benefit from her only to leave her in delicate situations. Marriage is not a protection for Maria, but the prerequisite for her exploitation in a moral and legal sense. In her relationship to Venables, her possessions become his property once they are married. Darnford's relationship with Maria leads to her committing adultery, which frees him from any moral responsibility towards her as it renders him liable to Venables for having violated the latter's 'possession'. Hence, the final example combines four different forms of comparing: first, Armida's garden is a metaphor for a state of romantic illusion, secondly it offers a comparison by use of imagery taking an enchanted garden as a representation of love. Here, the meaning constructed from metaphor and imagery overlap because with regard to Armida's garden the enchanted garden is an illusion, yet they form distinct comparative practices. Finally, by using Armida's garden as a

6 Here it is not necessary to debate if a metaphor is always a comparison, but it suffices to point out that certain metaphors are employed to invite comparisons following Walter Erhart's argument that "comparing is the key element and an essential dynamic operation in the practice and rhetoric of metaphors, tropes, and similes alike" (2020: 123). 
framework for making sense of the relationship between Maria and Darnford, their relationship is linked to Tasso's epic poem Jerusalem Delivered. The relationships between Armida and Rinaldo and between Maria and Darnford invite an intertextual comparison by explicitly mentioning Armida's garden.

The fact that both texts share narrative and plot features - such as the aspect of imprisonment, or the notion of love as a struggle for power over someone else and as a trap that leads to confinement, isolation, and even (attempted) suicide - invites a closer analysis. The different types of comparison outlined with the help of the first novel do not only co-occur but are entangled and work together to create ever more complex structures. Only the combination of all four comparative practices enables a reading of the text passage as an argument against marriage. Linking love to an illusion (metaphor) can only be understood as an argument against a power imbalance in marriage if the enchanted garden (imagery) is linked to the character Armida in Tasso's epic poem (intertextual) and the relationship of Maria and Darnford is read in the context of the narrative of Armida and Rinaldo (narrative). Only if all four comparative practices come together, a feminist argument can be constructed from the passage. If the intertextual or the narrative comparison are eclipsed or missed by the reader, the argument will not work anymore because elements such as the imprisonment in the garden are eliminated from the act of reasoning; Hence, the link to marriage cannot be made. While the narrative of Tasso's epic offers reconciliation at the end, Maria is not saved by a knight in shining armour but by a fellow woman (137). The romantic reconciliation of the epic remains a fantasy whereas the female protagonist of the novel can find comfort only by those in a similar situation, if at all. The harsh contrast only becomes apparent if all four forms of comparing are combined in a reading of the passage. On the other hand, it is also impossible to grasp only one of these types of comparing due to their interdependence and overlapping.

\section{Types of Comparing in The Female Quixote by Charlotte Lennox}

The second novel under consideration here, The Female Quixote by Charlotte Lennox, revolves around the incapability of the protagonist Arabella to compare and to differentiate her own situation from that of the protagonists in the French romance novels she consumes in great numbers. Arabella confuses the ontological levels on which she and these characters exist. Other characters in the text, such as the Doctor who admires Arabella's virtues yet tries 
to argue against romance fiction (374-375), compare her behaviour to an ideal standard of female conduct against which she is ridiculed and derided. The novel's plot thus displays a clear preoccupation with the topic of comparing - a preoccupation that is further highlighted by the title which provides an intertextual link to Miguel De Cervantes' Don Quixote (1605/1615). This link invites the reader to compare both texts and both protagonists, the male and the female Quixote. For this kind of reinvention of one character in terms of another (of Don Quixote in Arabella as a female Quixote), Walter Erhart, drawing on the example of Homer's Odyssey, argues that

variations of themes and figures in world literature constitute a practice of comparing not by mere transfer or 'adaptability' of famous literary characters, but by a comparative action that puts the traditional figure in relation to the newly invented figure through an established tertium comparationis that sorts out similarities and differences [...]. [T] he variations of figures and characters in world literature, their mythical qualities, are triggered by the dynamics of comparative practices. The Odyssey becomes a pre-text when its actions and characters, already borne out by comparative practices, appear in a new context, a post-text or - according to Cenette's terminology - in a 'hypertext' in which similarities and differences are worked out through a common framework, be it the theme of suffering or ingenuity or the narrative structure that the two texts have in common: sufferings with a happy ending, man fighting against natural powers, culture conquering the 'other,' homecoming. (2020: 118)

In other words, by installing Arabella as a female Quixote, the reader is immediately invited to compare both protagonists and to look for a shared framework in which both characters can be placed. To find this framework and to make sense of the relation between Arabella and Don Quixote, both texts must be compared in more detail to elucidate the numerous similarities in their narrative and plot structures: Both novels are cases of heterodiegetic narration and both protagonists have severe problems realizing the difference between the literary fiction they read and the reality of the storyworlds they inhabit. ${ }^{7}$ Both of them expect to find in 'real life' elements of the fictions they

Both texts are narrated from outside the story world and hence constitute heterodiegetic narratives. However, in the case of Don Quixote occasional breaks in the narrative in the form of metalepsis have been discussed. For a discussion of metalepsis in Don Quixote, see Levin (2016) and Patrick (2008). 
consume and based on this premise misinterpret the events they encounter. Finally, both texts can be considered metafictional because they discuss the power and the danger of fiction in fiction; both novels employ a humorous and occasionally ironic tone when talking about the virtues employed by the protagonists in accordance with the fictions they consumed (see Close 1973: 242; Mandel 1958: 161-162; Waugh 2011: 2). As we have seen, the title of The Female Quixote sets the novel into relation with De Cervantes' Don Quixote and invites the reader to compare both texts. This invitation to an intertextual comparison then calls for other literary practices of comparing in order to capture the full spectrum of the connection between both works that the title only hints at. The invitation to compare is thus not limited to one form of comparing, but rather invites diverse comparative practices in order to highlight similarities and difference between both texts. Here, especially narrative comparisons (including comparisons on the level of plot and narrative situation) support an intertextual comparison invited by the title and its variation of Don Quixote in the form of the female Quixote.

However, the intertextual comparison between Don Quixote and The Female Quixote not only highlights the similarities between both texts but also draws attention to their differences. In Don Quixote the reactions of the other characters towards Don Quixote's misconceptions tell us something about the protagonist. For instance, the reaction of the boy named Andrew whom Don Quixote meets along the way does not serve to indicate Andrew's level of serenity but highlights the level of Don Quixote's confusion (Don Quixote 265). The other characters serve as a canvas against which Don Quixote's ignorance is played out. Comparing both texts, it becomes clear that this situation is reversed in The Female Quixote. The other characters correct Arabella's mistake and speak out against the risk of consuming too much romance fiction. Yet, while they do ridicule her ignorance towards the distinction of fiction and reality, a distinction that requires comparing, they meet her with admiration and do not speak out against the virtues depicted in the romance fiction she consumes (The Female Quixote 148-150, 376-377, 379-381). Their response highlights the paradox of the romance novel in The Female Quixote that is, much like Arabella, both valued and ridiculed by the other characters. Hence, the focus is moved away from the female Quixote to the perception of her confusion by the other characters within the story. In other words, the novel can not only be read as a parody of Don Quixote, but also as a comment on its perception in eighteenth-century British cultural discourses (see More 1799: 2023). Arabella's misunderstanding serves as a comment on the society around 
her. The characters installed around Arabella openly mock her for taking her French romance novels as historically accurate (The Female Quixote 121-122, 142). However, the mockery remains ambiguous, and is not directed exclusively at Arabella. Instead, the reaction of the other characters to Arabella's obsession with romance novels reflects the perception of the genre of the novel, in general, and Don Quixote, in particular, by eighteenth-century British society a society that, while increasingly consuming novels, also warned against the dangers of this new genre (see More 1799: 23, 31; Watt 2006: 22, 42-43). This ambiguous positioning towards fiction is highlighted by inviting comparisons between both novels, between Arabella and the other characters' response to her, and by contrasting fiction with the expectations of a society that is nevertheless considerably shaped by the fictions it consumes (see More 1799: 20-23; Martin 1997: 57-58). Yet, even harsh criticism of romance novels did not necessarily imply a rejection of the novel or even the genre as such, as becomes apparent in Hannah More's Strictures on the Modern System of Female Education (1799). More warns of the "thousand mischiefs" of romance novels and yet praises the virtues depicted in these novels as having "formed the ancient texture of British manners" (20-23). In other words, The Female Quixote addresses expectations that are shaped by fictions, by comparing fiction and the expectations it installs. It reveals that Arabella is not the only character whose expectations are shaped by fiction albeit Arabella takes things to an extreme. The novel continuously coquettes with the blurring of fictional narratives and social expectations, constructing a tertium comparationis in the form of Arabella's virtue that is a shared element between the two.

Arabella does not blindly copy the female conduct displayed in romance novels but does so for specific purposes. This is highlighted when Arabella instructs her maid on how to tell her narrative (121-122) and when Miss Glanville directly brings up the topic of comparison (142-143). While the former part unmasks Arabella's behaviour as a performance carefully constructed in accordance with what she assumes is expected, the latter contrasts her performance with her capabilities and warns against taking Arabella's performance of the presumably expected for naivety or simple-mindedness. Martin convincingly argues that

as Miss Clanville gaily displays her ignorance, becoming the unwitting object of her own raillery, Arabella's status in the satire is shifted, and new value granted to her learning and intelligence. While Arabella is admittedly sometimes foolish, she is never a fool. (1997: 55) 
Arabella's response to Miss Glanville's mockery, which is going too far and eventually turns against herself, invites a comparison between both characters' reactions. It offers similar structural elements. Both women find themselves in powerful positions because the respective other made a mistake and both women can openly point out this mistake to put the respective other down. Miss Glanville makes use of this opportunity, but Arabella is "unwilling to expose her Cousin's Ignorance, by a longer Dispute upon the Subject", which puts Arabella in the morally higher position (The Female Quixote 143). Whereas Miss Glanville takes the opportunity to ridicule Arabella, Arabella does not belittle Miss Glanville and once made aware of her mistake in taking romance novels as historically accurate, she accepts Mr Glanville in marriage (379).

Arabella's mistake was not that she did not behave as was expected of her, or that her assumption of these expectations was wrong, but that she overdid it and thereby rendered these expectations ridiculous. All the while the society that seemingly condemns romance novels as a young woman's guilty pleasure holds on to the virtues proclaimed by romance novels (370-371, 374). Arabella does not fall out of favour for copying and performing these virtues in social contexts, but because she does so in a way that betrays romance novels as their source and by doing so questions the virtues she performs by the very act of their performance. She destabilizes the social order by openly performing a masquerade of the fiction of womanhood, yet presumably not for the purpose of protesting against the existing social conventions but by mere accident. However, the accident only occurs because she does not know any better. Once the mistake is pointed out to her and Arabella 'learns' about her misunderstanding she immediately takes up her predestined position in society as Mr Glanville's wife (383; see Meyer Spacks 1988: 536). The moment Arabella realizes her mistake is a turning point in the novel separating the narrative and her behaviour into before and after this realization (376-378), which invites a comparison between the uniformed and the informed Arabella. With this, the novel suggests that an uneducated woman might be an even greater risk to society than an educated one. Lennox certainly does not speak up for female education with the same rigour as Mary Wollstonecraft in Maria; Or, The Wrongs of Woman, but her novel nevertheless offers an experiment of a young woman exposed to British eighteenth-century society without receiving the necessary education to manoeuvre herself safely through this environment. This poses an antithesis to the concept of an educated woman as a risk to the 
social order and offers an image of education as enabling women to take up their position in society (Wyett 2015: 9).

\section{Types of Comparing and Their Function}

My exploration of the different forms of comparing in the two novels by Wollstonecraft and Lennox has revealed three recurring types of comparisons, namely narrative comparisons (including comparisons on the level of discourse, story, plot, etc.), imagery comparisons (including comparisons triggered by simile, metaphor, parables, etc.), and intertextual comparisons (invited by different types of references to other texts). The three types of comparing I have identified in the two novels are not mutually exclusive nor exhaustive, but they offer a preliminary overview of the comparative practices employed in both texts. All three mainly fall under the category of indirect comparisons and thus illustrate that the distinction between direct and indirect comparisons is too simple and needs to be further refined. Moreover, especially intertextual comparisons and comparisons by narrative structure seem to have a high likelihood of working together to construct more complex meanings not just from each individual comparative practice, but by creating a surplus of meaning exactly in the entanglement of both practices. In such cases narrative comparisons might therefore appear as a subcategory of intertextual comparisons. However, not all narrative comparisons need to point at other texts as was indicated by the autobiographic narrative of Jemima and Maria in Wollstonecraft's novel. Thus, the relation of narrative and intertextual comparison must be a more complex one. The relation of narrative comparisons and intertextual comparisons needs further research and this point can only be hinted at. Most importantly, it needs to be tested in the context of a bigger corpus.

My findings indicate that comparisons of one type often invite other types of comparisons, as was the case with Armida's garden in Maria; Or, The Wrongs of Woman where the recognition of Armida's garden as a metaphor for romantic illusion automatically points the reader to the epic by Tasso and invites a narrative and intertextual comparison. Occasionally, however, certain practices are employed individually in order to support certain arguments posed by the text. In the imbedded narratives of Maria and Jemima, only a narrative comparison between the two is invited. While other comparative practices are employed especially in Jemima's story, the comparison of both women is lim- 
ited to their life stories. Here, in what Erhart (2020:117) terms an inner-textual comparison, the comparison is kept simple to foster the construction of the relationality between Jemima and Maria. The narrative structure highlights their shared struggles as women which are exacerbated by an unbalanced power relation to men either modulated by family structures, class structures or marriage. It poses an argument against class injustice and gender divides by constructing a relation between womanhood and slavery in the autobiographies of both women (Maria 11). If the comparison between the two women is not established, even the genre ascribed to the novel can change. The categorisation under a specific genre influences how a novel is perceived, as becomes apparent in More's (1799) discussion of Maria; Or, The Wrongs of Woman. While critical of romance novels, More speaks out vehemently against Wollstonecraft's novel. In the case of Maria; Or, The Wrongs of Woman the novel can be read as a romance novel based on the unhappy love plots between Maria and George and between Maria and Darnford. However, especially when a greater focus is put on the two women narrating their life stories, the socio-political argument against absolute authorities is foregrounded and the novel can be read as a Jacobin novel. Jacobin novels evolved at the end of the eighteenth-century and were "inspired by the events in France and fuelled by the controversies which followed Burke's Reflections on the Revolution in France" (Watson 1992: 146). Jacobin novels posed social political arguments against monarchy and absolutism. Hence, depending on the focus of the reader the novel is turned from a Jacobin novel engaging with matters of class and gender divides, to a romance novel (Johnson 2004: 103). Here, the feminist argument against marriage is linked to an argument against Absolutism. The power position of the husband over wife and children is linked to the power of the monarch over the state. Thus, the practices of comparing employed are decisive for the meaning construction and positioning of the argument structure of the novel in the discourses of its time. Only if read as a Jacobin novel based on the narrative comparison of both women can the criticism of the novel by Hannah More be contextualized (1799: 31).

In the case of the The Female Quixote, one aspect needs further attention before closing the discussion, and that is the relation between comparison and parody. A parody always invites a comparison between the parody and that which is parodied. Gray, Jones and Thompson distinguish between satire which "draws on social conventions" and parody which "draws on aesthetic ones" (2009: 17). According to this approach, when looking at parody one looks at formal features in a text and how these features are enacted. The parody 
must repeat these formal elements of that which it parodies yet it must walk the fine line between repeating these elements without becoming that which it parodies. This can be achieved by repeating some, but not all elements or by rearranging or recontextualising the repeated elements. Hence, if the(se) shared elements are added in great number, the parody paradoxically deviates and repeats the original simultaneously. Since a parody repeats mainly formal features, it might be considered a performative practice of literature. The repetition invites readers to compare and the deviation in the performance has the potential to subvert the argument of the parodied text. Phiddian pays tribute to this dilemma when he states that, in order to succeed, "Parodies can't live with their host discourses, and they can't live without them" (1997: 682). For this intermediate position of parody between deviation and repetition, Laurent argues that parody can be seen as a technique to "keep meaning from becoming lethargic" (59). It is a way of negotiating meaning by the comparative confrontation of the parody with its source texts. Parodies in novels according to the suggested grouping above fall under intertextual comparisons and support the statement by Angelika Epple and Walter Erhart that comparisons are "instruments of power" (2015: 15) and as such ideologically charged. However, Lennox's novel is a complex intertextual comparison because it does not limit itself to two comparata. Instead, it simultaneously draws on romance novels, Don Quixote and the perception of both in eighteenth-century British society, hence creating a relation between four entities. The complex meaning can only be constructed from this comparison by making oneself familiar with all four sources. It is not enough to be familiar with romance novels, Don Quixote and the text by Lennox, but rather the public discussion of all three such as offered by More (1999) must be taken into consideration as well. ${ }^{8}$ The ambiguity of her remarks about romance novels and the praise of Don Quixote offer a tension of rejection and admiration that is echoed in the argumentative structure of the The Female Quixote. Hence, it critically highlights that Arabella is ridiculed leading to argue that Lennox took the text by More into consideration when writing her novel. However, More's text can be taken as exemplary for the ambivalent discourses on romance novels at the time. It was chosen for the paper because it addresses female education in Maria; Or, The Wrongs of Women, romance novels and Don Quixote, and hence offers a particularly suiting source for a discussion of both novels in terms of the arguments they pose on female education. 
for taking romance novels as historically accurate yet idolized for upholding the virtues of these novels.

\section{Conclusion}

This chapter analyzed practices of comparing in Maria; Or, The Wrongs of Woman by Mary Wollstonecraft and The Female Quixote by Charlotte Lennox to argue that the comparative practices employed in novels are not innocent but are invoked in support of certain ideologically charged arguments. In Maria; Or, The Wrongs of Woman, the narrative comparison between Jemima and Maria turns the novel from a romance to a Jacobin novel, conveying a feminist argument against marriage that is entangled with an argument against the political order and in favour of a better position for women in eighteenth-century British society. Hence the narrative comparisons between Jemima and Maria do not just support the arguments presented in the novel; rather, the comparative practices employed in the text provide no less than the basis on which the arguments of the novel are built upon. In The Female Quixote, the intertextual comparison between Lennox's novel and Don Quixote by De Cervantes offers the framework in which the novel parodies romance novels and their perception in eighteenth-century Britain.

Certain arguments developed in the novels analyzed here are difficult to construct from the text unless comparative practices receive more attention and are included in the examination of those texts. Based on the heuristic distinction between direct and indirect comparisons suggested by Hartner and Schneider with an added subgrouping into narrative, imagery and intertextual practices of comparing, the chapter suggested that literary practices of comparing can co-occur and build complex networks that can contribute to creating multi-layered argumentative structures within a novel. By taking into consideration not just who compares what, and for what purpose, but taking a closer look at the textual practices employed in a literary work, the underlying ideological premises of the ideas posed in a novel can be addressed. In Wollstonecraft's novel marriage is compared to a form of slavery, while Lennox employs intertextual comparisons and narrative comparisons to outline the ambiguous position in British society towards romance novels and the female virtues they propagate. Both novels pose strong feminist arguments, and both do so by employing certain practices of comparing. Thus, 
to outline the underlying ideological investment in a novel, it is necessary to analyze how novels compare.

\section{Bibliography}

Allen, Graham. Intertextuality. New York: Routledge, 2000.

Aristotle, W. R. Roberts, Ingram Bywater, Friedrich Solmsen, and Aristotle. Rhetoric. New York: Modern Library, 1954.

Close, Anthony J. "Don Quixote's Love for Dulcinea: A Study of Cervantine Irony." Bulletin of Hispanic Studies (Liverpool) 50.3 (1973): 237.

Cope, Edward Meredith. An Introduction to Aristotle's Rhetoric: With Analysis, Notes and Appendices. Macmillan, 1867.

De Cervantes, Miguel Saavedra. The Ingenious Hidalgo Don Quixote De La Mancha. Trans. John Rutherford. Penguin, 2003.

Durant, Will and Ariel Durant. The Age of Reason Begins. Simon and Schuster, 1961.

Eggers, Michael. "Outlines of a Historical Epistemology of Comparison: From Descartes to the Early Nineteenth Century." The Force of Comparison: A New Perspective on Modern European History and the Contemporary World. Ed. Willibald Steinmetz. New York: berghahn, 2019. 33-52.

Epple, Angelika and Walter Erhart, eds. Die Welt beobachten - Praktiken des Vergleichens. Frankfurt: Campus Verlag, 2015.

Erhart, Walter. "Odysseus, Blackbirds, and Rain Barrels." Practices of Comparing. Bielefeld University Press, transcript, 2020. 111-136.

Evans, Vyvyan and Melanie Green. Cognitive Linguistics: An Introduction. Edinburg: Edinburg University Press, 2006.

Gray, Jonathan et al. Satire TV: Politics and Comedy in the Post-Network Era. New York: New York University Press, 2009.

Hale, Matthew, George Wilson and Sollom Emlyn. The History of the Pleas of the Crown. Vol. 1. T. Payne et al., 1778.

Han, Tan Cheng. "Marital Rape-Removing the Husband's Legal Immunity." Malaya Law Review 31 (1989): 112-128.

Johnson, Nancy E. The English Jacobin Novel on Rights, Property and the Law: Critiquing the Contract. Basingstoke: Palgrave Macmillan, 2004.

King, Rebecca Frances. Rape in England 1600-1800: Trials, Narratives and the Question of Consent. Durham theses, Durham University, 1998. 
Kramer, Kirsten et al. "Vergleichen und Erzählen. Zur Verflechtung zweier Kulturtechniken.” Working Paper des SFB 1288, No. 4 (2020). Accessed online, 15 August 2021. 〈https://pub.uni-bielefeld.de/record/2946608〉.

Lakoff, George and Mark Johnson. Metaphors We Live By. Chicago: University of Chicago Press, 2003.

Laurent, Jenny. "The Strategy of Form." French Literary Theory Today: A Reader. Ed. Tzvetan Todorov. Cambridge: Cambridge University Press, 1982. 3463.

Lennox, Charlotte and Margaret Dalziel. The Female Quixote, or, The Adventures of Arabella. Oxford: Oxford University Press, 2008 [1752].

Levin, Yael. "Metalepsis and the Author Figure in Modernist and Postmodernist Fiction." Twentieth Century Literature 62.3 (2016): 289-308.

Mandel, Oscar. "The Function of the Norm in Don Quixote." Modern Philology 55.3 (1958): 154-163.

Martin, Mary Patricia. "High and Noble Adventures: Reading the Novel in The Female Quixote.” Novel: A Forum on Fiction. 31.1 (1997): 45-62.

Meyer Spacks, Patricia. "The Subtle Sophistry of Desire: Dr. Johnson and "The Female Quixote"." Modern Philology 85.4 (1988): 532-542.

More, Hannah. Strictures on the Modern System of Female Education: With a View of the Principles and Conduct Prevalent Among Women of Rank and Fortune. By Hannah More. In Two Volumes. Vol. 1. T. Cadell jun. and W. Davies, 1799.

Patrick, Brian D. "Metalepsis and Paradoxical Narration in Don Quixote: A Reconsideration." Letras Hispanas 5.2 (2008): 116-132.

Phiddian, Robert. "Are Parody and Deconstruction Secretly the Same Thing?" New Literary History 28.4 (1997): 673-696.

Punter, David. Metaphor. London: Routledge, 2007.

Schneider, Ralf. "Comparison, Analogy, and Knowledge in Literature: Basic Considerations and the Case of Early Modern English Texts." Analogy, Copy, and Representation: Interdisciplinary Perspectives. Ed. Christoph Haase and Anne Schröder. Bielefeld: Aisthesis, 2017. 137-154.

Tasso, Torquato. Jerusalem Delivered: An English prose version. Detroit: Wayne State University Press, 1987.

Taylor, Barbara. Mary Wollstonecraft and the Feminist Imagination. Cambridge: Cambridge University Press, 2003.

Watson, J. R. "The Jacobin Novel." A Handbook to English Romanticism. Ed. Jean Raimond. London: Palgrave Macmillan, 1992. 146-149.

Watt, Ian P. The Rise of the Novel: Studies in Defoe, Richardson and Fielding. Berkeley: University of California Press, 2006. 
124 Anne Lappert

Waugh, Patricia. Metafiction: The Theory and Practice of Self-Conscious Fiction. London: Routledge, 2011.

Wollstonecraft, Mary. The Vindications: The Rights of Men and The Rights of Woman. Peterborough: Broadview Press, 1997.

Wollstonecraft, Mary. Maria; Or, The Wrongs of Woman. New York: W. W. Norton, 1994 [1798].

Wyett, Jodi L. "Quixotic Legacy: The Female Quixote and the Professional Woman Writer." Authorship 4.1 (2015): 1-19. 